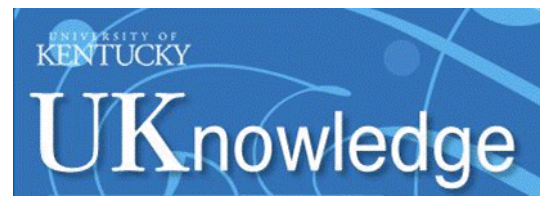

University of Kentucky

UKnowledge

Molecular and Cellular Biochemistry Faculty

Publications

Molecular and Cellular Biochemistry

3-10-2017

\title{
Editorial: Platelet Secretion
}

Brian Storrie

University of Arkansas for Medical Sciences

Sidney W. Whiteheart

University of Kentucky, whitehe@uky.edu

Follow this and additional works at: https://uknowledge.uky.edu/biochem_facpub

Part of the Biochemistry, Biophysics, and Structural Biology Commons

Right click to open a feedback form in a new tab to let us know how this document benefits you.

\section{Repository Citation}

Storrie, Brian and Whiteheart, Sidney W., "Editorial: Platelet Secretion" (2017). Molecular and Cellular Biochemistry Faculty Publications. 163.

https://uknowledge.uky.edu/biochem_facpub/163

This Article is brought to you for free and open access by the Molecular and Cellular Biochemistry at UKnowledge. It has been accepted for inclusion in Molecular and Cellular Biochemistry Faculty Publications by an authorized administrator of UKnowledge. For more information, please contact UKnowledge@lsv.uky.edu. 


\section{Editorial: Platelet Secretion}

Digital Object Identifier (DOI)

https://doi.org/10.1080/09537104.2016.1277676

\section{Notes/Citation Information}

Published in Platelets, v. 28, issue 2, p. 107.

(C) 2017 Taylor \& Francis

The copyright holder has granted the permission for posting the article here.

This is an Accepted Manuscript of an article published by Taylor \& Francis in Platelets 10 Mar 2017, available online: http://www.tandfonline.com/10.1080/09537104.2016.1277676. 
\begin{tabular}{|l|l|}
\hline $\begin{array}{l}\text { Author manuscript } \\
\text { Platelets. Author manuscript; available in PMC } 2017 \text { December } 09 .\end{array}$ & $\begin{array}{l}\text { HHS PUblic ACCESS } \\
\text { Published in final edited form as: }\end{array}$ \\
\hline
\end{tabular}

Platelets. 2017 March ; 28(2): 107. doi:10.1080/09537104.2016.1277676.

\title{
Editorial: Platelet Secretion
}

\author{
Brian Storrie $^{1}$ and Sidney W. Whiteheart ${ }^{2}$ \\ ${ }^{1}$ Department of Physiology and Biophysics, University of Arkansas for Medical Sciences, Little \\ Rock, AR, USA \\ ${ }^{2}$ Department of Molecular and Cellular Biochemistry, University of Kentucky, Lexington, KY, USA
}

\begin{abstract}
These are exhilarating times for platelet researchers. Through the applications of new technologies (e.g., high resolution imaging, mass spectrometry, and DNA/RNA profiling), we continue to discover new facets of platelet biology; ones that have surprising effects on platelet function. It is increasingly clear that platelets are capable of many cellular processes i.e. mRNA splicing, translation, endocytosis, autophagy, and exocytosis. These discoveries have shown that platelets are much more dynamic than was perhaps previously appreciated and have illuminated the mechanisms by which platelets not only contribute to hemostasis but also to immune responses.
\end{abstract}

In this collection of reviews, we survey the exciting new discoveries about platelets and their secretory granules. We examine granule formation, content, structure and secretion and their implications for platelet function. Secretion is the process by which platelets, in response to stimulation, release cargo from three classes of storage granules: dense $(\delta)$ granules, alpha (a) granules, and secretory lysosomes. This is a key process that enables platelets to have profound effects on the microenvironments at sites of vascular damage and infection. Dysfunction in platelet secretion has significant clinical ramifications. The included reviews discuss the structures of platelet granules and secreting platelets, the composition and heterogeneity of the platelet releasate, and the molecular mechanisms of the secretion process. Two reviews on platelet "granulopathies" relate what is known about dense and alpha granule biogenesis to how dysfunction contributes to disease and illuminates normal granule function. Finally, the clinical importance of platelet secretion is discussed. In each review, the authors have summarized the state of knowledge, as well as the technologies used, and attempted to identify areas where future research is needed. It is our hope that this collection will serve as a valuable introduction to newcomers to the field and thoughtprovoking reading for those well-versed in the topic.

We, the editors and authors, offer this collection as a tribute to Dr. James G. White, MD, who died this past summer. Dr. White, either directly or indirectly, affected all of us through his micrographs and insights. His more than 700 publications and textbook chapters shaped how we "see" platelets and laid the foundations for much of the work discussed in these reviews. We are indebted to Dr. White for the path he forged for more than 50 years, for the scientific standards that he upheld, and for his infectious enthusiasm for these intriguing "little cells". 

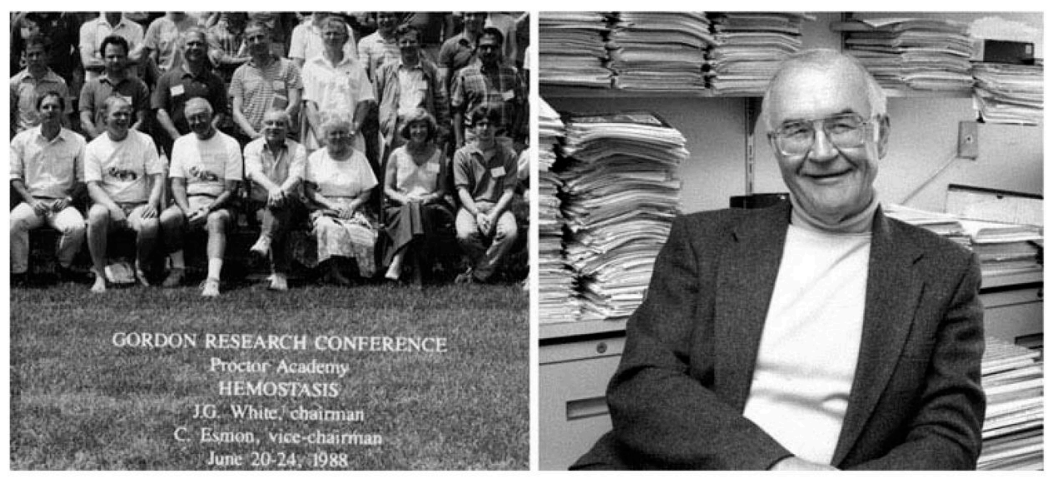

Figure 1. Dr. James G. White, 1929-2016

Left: In 1988, Dr. White served as the chair of the Hemostasis and Thrombosis Gordon Conference. He is above the " $\mathrm{R}$ " in Research. The picture is used with permission of the GRC and generously provided by Dr. Nancy Gray and Jeff Carroll. Right: Dr. White in his office at the University of Minnesota. Picture generously provided by Dr. Leo Furcht and Linda Kenny, Department of Laboratory Medicine and Pathology, University of Minnesota, Medical School. 